\title{
The Adaptive Consequences of Pride in Personal Selling
}

\author{
Willem Verbeke, Frank Belschak and Richard P. Bagozzi
}

\begin{tabular}{|l|l|}
\hline ERIM REPORT SERIES RESEARCH IN MANAGEMENT \\
\hline ERIM Report Series reference number & ERS-2004-012-MKT \\
\hline Publication & January 2004 \\
\hline Number of pages & 46 \\
\hline Email address corresponding author & verbeke@few.eur.nl \\
\hline Address & Erasmus Research Institute of Management (ERIM) \\
& Rotterdam School of Management / Rotterdam School of \\
& Economics \\
& Erasmus Universiteit Rotterdam \\
& P.O. Box 1738 \\
& 3000 DR Rotterdam, The Netherlands \\
& Phone: $\quad+31104081182$ \\
& Fax: $\quad+31104089640$ \\
& Email: info@erim.eur.nl \\
& Internet: www.erim.eur.nl \\
\hline
\end{tabular}

Bibliographic data and classifications of all the ERIM reports are also available on the ERIM website: www.erim.eur.nl 


\title{
ERASMUS RESEARCH INSTITUTE OF MANAGEMENT
}

\author{
REPORT SERIES \\ RESEARCH IN MANAGEMENT
}

\begin{tabular}{|c|c|c|}
\hline \multicolumn{3}{|c|}{ BIBLIOGRAPHIC DATA AND CLASSIFICATIONS } \\
\hline Abstract & \multicolumn{2}{|c|}{$\begin{array}{l}\text { Study } 1 \text { investigates the beneficial effects of experiencing pride. Pride was found to have two } \\
\text { different effects. First, it increases salespersons' performance-related motivations. Specifically, } \\
\text { it promotes adaptive selling strategies, greater effort, and self-efficacy. Secondly, it positively } \\
\text { affects organizational citizenship behaviors. Study } 2 \text { takes an emotion-process point of view } \\
\text { and compares excessive pride (hubris) with positive pride. The results show that salespeople } \\
\text { are capable of self-regulating the expression of these emotions via anticipated feelings of fear, } \\
\text { shame, and regret. Salespeople in other words are affected by their emotions, but they also are } \\
\text { capable of controlling them to their advantage. }\end{array}$} \\
\hline \multirow{3}{*}{$\begin{array}{l}\text { Library of Congress } \\
\text { Classification } \\
\text { (LCC) }\end{array}$} & $5001-6182$ & Business \\
\hline & $5410-5417.5$ & Marketing \\
\hline & HF 5438.4 & Sales management \\
\hline \multirow{3}{*}{$\begin{array}{l}\text { Journal of Economic } \\
\text { Literature } \\
\text { (JEL) }\end{array}$} & M & Business Administration and Business Economics \\
\hline & $\begin{array}{l}\text { M } 31 \\
\text { C } 44\end{array}$ & $\begin{array}{l}\text { Marketing } \\
\text { Statistical Decision Theory }\end{array}$ \\
\hline & M 31 & Marketing \\
\hline \multirow{3}{*}{$\begin{array}{l}\text { European Business Schools } \\
\text { Library Group } \\
\text { (EBSLG) }\end{array}$} & $85 \mathrm{~A}$ & Business General \\
\hline & $\begin{array}{l}280 \mathrm{G} \\
255 \mathrm{~A}\end{array}$ & $\begin{array}{l}\text { Managing the marketing function } \\
\text { Decision theory (general) }\end{array}$ \\
\hline & $290 \mathrm{~s}$ & Selling \\
\hline \multicolumn{3}{|c|}{ Gemeenschappelijke Onderwerpsontsluiting (GOO) } \\
\hline \multirow[t]{3}{*}{ Classification GOO } & 85.00 & Bedrijfskunde, Organisatiekunde: algemeen \\
\hline & $\begin{array}{l}85.40 \\
85.03\end{array}$ & $\begin{array}{l}\text { Marketing } \\
\text { Methoden en technieken, operations research }\end{array}$ \\
\hline & 85.40 & Marketing \\
\hline \multirow[t]{3}{*}{ Keywords GOO } & \multicolumn{2}{|c|}{ Bedrijfskunde / Bedrijfseconomie } \\
\hline & \multicolumn{2}{|c|}{ Marketing / Besliskunde } \\
\hline & \multicolumn{2}{|c|}{ Account management, Verkooptechnieken, Trots, prestatiebeoordeling } \\
\hline Free keywords & \multicolumn{2}{|c|}{ Pride, hubris, work motivation, organizational citizenship behaviors, meta-emotions } \\
\hline
\end{tabular}


The Adaptive Consequences of

Pride in Personal Selling

\author{
Willem Verbeke ${ }^{1}$, \\ Frank Belschak ${ }^{2}$, and \\ Richard P. Bagozzi ${ }^{3}$
}

(1) Willem Verbeke is Chair Professor in Sales and Account Management in the Marketing and Organization Department, Faculty of Economics, Erasmus University Rotterdam; P.O. Box 1738, 3000 DR Rotterdam, The Netherlands; phone: +31-10-4081308; fax: +31-10-4089169; email: verbeke@few.eur.nl

(2) Frank Belschak is Assistant Professor in the Marketing and Organization Department, Faculty of Economics, Erasmus University Rotterdam; P.O. Box 1738, 3000 DR Rotterdam, The Netherlands; phone: +31-10-4081308; fax: +31-10-4089169; email: belschak@few.eur.nl (3) Richard P. Bagozzi is the J. Hugh Liedtke Professor of Management, the Jesse H. Jones Graduate School of Management, and Professor of Psychology, Department of Psychology, Rice University, Houston, Texas, 77005, USA; MS-531; phone: 713-348-6307; fax: 713-348-5251; email: bagozzi@rice.edu 


\begin{abstract}
Study 1 investigates the beneficial effects of experiencing pride. Pride was found to have two different effects. First, it increases salespersons' performance-related motivations. Specifically, it promotes adaptive selling strategies, greater effort, and self-efficacy. Secondly, it positively affects organizational citizenship behaviors. Study 2 takes an emotion-process point of view and compares excessive pride (hubris) with positive pride. The results show that salespeople are capable of selfregulating the expression of these emotions via anticipated feelings of fear, shame, and regret. Salespeople in other words are affected by their emotions, but they also are capable of controlling them to their advantage.
\end{abstract}


In order to fire up front line personnel, organizations attempt to instill pride in their employees (Katzenbach and Santamaria 1998) because pride functions as a resource, motivating employees and enhancing their goal attainment (Fredrickson 2002; Brown, Cron, and Slocum 1997). Feelings of pride emerge when salespeople experience personal worth because they match or even exceed expectations with respect to performance. Expectations refer to salespeople's own internalized standards of achievement as well as the standards of other persons that are significant to them, for instance their sales managers. As a consequence, managers can intentionally stimulate and manage the pride in their salespeople.

Such organizations as Mary Kay use elaborate rituals in which management visibly expresses its approval publicly to its employees when they have exceeded or matched company goals (Kay Ash 1995). As the emerging literature on positive psychology shows, feelings of pride should make a salesperson more self-assured (promoting assertiveness in relation to different members of their role set), more creative and flexible, as well as more altruistic (see Fredrickson 2001, 2002; Bagozzi, Gopinath, and Nyer 1999). Indeed, researchers stress that pride has adaptive social functions (Barret 1995).

But pride also has a dark side (Tangney 1999). At times pride induces overconfidence and leads to displays of conceit and egotistic behaviors, which, in turn, threaten one's social capital and one's sales performance. Such excessive pride is called hubris in the literature (Lewis 2000; Fischer and Tangney 1995). Similarly, when employees witness the pride displayed by others, which draws attention to their own performance and one's relative frailness, feelings of envy can result. Because salespeople are embedded in networks with others in and outside their organization (e.g. Rindfleisch and Moorman 2001; Ibarra 1992), it is important that they learn to manage the expression of their pride in nondisruptive ways (Salovey et al. 2000).

The goal of this paper is to study the way salespeople feel and experience pride and the effects 
that this has on their in-role performance (sales performance-related motivations) and extra-role performance (organizational citizenship behaviors). First, we present the results of a pre-study designed to empirically determine to what extent pride is a salient emotion within personal selling. Specifically, compared to nine other emotions, pride is shown to be perceived as a frequently and intensely experienced emotion by salespeople. We then focus in Study 1 on the consequences of pride. More specifically, we seek to study how pride affects a salesperson's behavior and enhances the way s/he seeks to achieve multiple goals (in-role and extra-role performance), thus illustrating adaptive functions of this positive emotion. Next, in Study 2, we take a process point of view and show how excessive pride (hubris), and positive pride (beta pride) unfold and how salespeople self-regulate these emotions. Building on Fischer and Tangney's (1995) work on meta-emotions, we propose a theory of how salespeople self-regulate their emotions so as to coordinate and fit in with different members of their role set. Finally, we discuss implications of our research for management and suggest future research topics.

\section{PRIDE AS A SELF-CONSCIOUS EMOTION}

Self-conscious emotions, like shame, pride, or guilt, emerge when a person's “I” (one's self as an active agent) reflects on and becomes conscious of his/her "Me" (one's categorical or social self). Under this process, the "I" takes the "Me" as an object of self-reflection and self-evaluation (Harter 1999). Pride specifically emerges when a person reaches or exceeds social standards or expectations (Fischer and Tangney 1995; Lewis 2000). A person may adopt such standards from significant others (e.g. their parents) and make them his/her own, but people significant to the person (for instance, one's supervisor) will also be able to instill pride by providing feedback whether a specific action has met their standards or expectations. These social cues are self-relevant to the person, that is, they center on people's reputation concerning how well they accomplish their goals within their social environment (Parkinson 1995). It is the evaluation of the "Me" by the "I" that creates a new selfcategorization and brings pride into consideration. Such self-categorizing is an ever-continuing 
dynamic process that lasts as long as one remains in one's organization (Feldman 1976; 1981). Pride emerges as a consequence of emotional appraisal processes (Bagozzi, Gopinath, and Nyer 1999) where particular positive evaluations of self-produced performance yield the typical appraisal pattern for pride. (Ruth, Brunel, and Otnes 2002). Specifically, a person's internal attribution of achievements to one's specific self arise when one is publicly complimented by others. Defined from a phenomenological perspective, the typical appraisal/attribution pattern for pride is experienced as a self-categorization (for example, "Now I know quite well what I have to do to be a good salesperson") that is subjectively experienced as positive feelings: e.g., "I feel proud" or "I feel exhilarated" (see Lewis 2000).

\section{PRE-STUDY}

A study on pride is only of practical relevance for sales if that emotion is frequently and intensely experienced within the selling context. Therefore, we asked 141 salespeople to indicate on 7point scales how frequently $(1=$ never, $7=$ always $)$ and intensely $(1=$ not at all, $7=$ very intensely $)$ they experienced 6 different self-conscious emotions (i.e., shame, embarrassment, guilt, pride, hubris, and envy) and 4 classic basic emotions (i.e., joy, disappointment, anger, and fear) in their work situations. The salespeople worked in the financial sector and spent at least 30 percent of their time with customers. The sample can be described as follows: a majority (about 87\%) of the salespeople were men, about $10 \%$ of the salespeople were younger than 30 years old, $48 \%$ were between 30 and $40,34 \%$ between 40 and 50 , and $8 \%$ was older than 50 . With respect to experience, about $8 \%$ of the sample had been with the organization less than 2 years, $28 \%$ had been with the firm between 2 and 6 years, and $64 \%$ were with the company from 7 to 20 years. Finally, $15 \%$ graduated with basic or advanced vocational training, while $85 \%$ had a university or college degree.

Table 1 summarizes the findings. As can be seen in the top panel, pride and joy are the most frequently experienced emotions at work, while all other emotions (whether self-conscious or basic) are experienced at relatively lower frequencies and are more or less equal in this regard. Note, 
however, that the felt frequency of occurrence of hubris still approaches moderate levels. The second panel in Table 1 shows that pride (together with joy) is also the most intensely felt emotion, with somewhat lower levels of intensity felt for each of the other emotions. It should be noted, however, that hubris is felt at moderately intense levels. Despite the apparent prevalence and salience of pride for salespeople, the focus of research on emotions within personal has been on negative rather than positive emotions (e.g., Verbeke and Bagozzi 2000, 2002, 2003). We know little about the functions of pride in personal selling.

[Table 1 about here]

\section{STUDY 1. BENEFICIAL EFFECTS OF PRIDE ON SALESPEOPLE'S MULTIPLE GOALS}

We seek to study the adaptive effects of pride in Study 1. We conceive of salespeople as

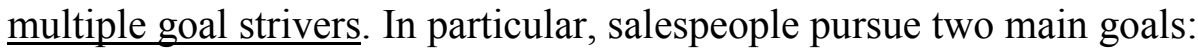

- First, salespeople seek to accomplish in-role performance goals. In-role performance is defined as those officially required outcomes and behaviors that directly serve the mission of the organization (Motowidlo and Van Scotter 1994). Among other things, in-role performance includes meeting sales objectives and executing effective sales presentations (e.g., Behrman and Perreault 1984). As many studies show, sales performance is positively related to motivational variables, particularly self-efficacy, willingness to work hard, and adaptive selling strategies (e.g., Spiro and Weitz 1990; Sujan 1986; Szymanski 1988; Lambert, Marmorstein, and Sharma 1990; Szymanski and Churchill 1990; Goolsby, Lagace and Boorom 1992; Sujan, et al. 1994).

- Second, salespeople strive at times to achieve extra-role performance goals (Morrison 1994). Extra-role performances are defined as discretionary behaviors on the part of salespeople that indirectly influence the effective functioning of an organization, without necessarily influencing a salesperson's own in-role performance (e.g., MacKenzie, Podsakoff, and Fetter 1991). Examples are willingness to help colleagues who have heavy workloads (henceforth termed, "helping"), making a point to be courteous to others ("courtesy"), avoiding creating 
problems with colleagues ("sportsmanship"), and suggesting improvements for practices in the organization ("civic virtue"). Extra-role performance is also known as "organizational citizenship behaviors" in the literature (Organ and Paine 1999; Bolino 1999).

\section{Study 1 hypotheses}

Pride is a positive self-conscious emotion, and as Fredrickson (e.g., 2001, 2002) argues, positive emotions trigger different responses than negative emotions. Fredrickson observes that current research on emotions, whether self-conscious or not, has been inspired by the negative emotions, specifically by negative feelings generating particular action tendencies (such as flight-orfight responses in anxiety) (e.g., Frijda 1986), thus leaving out other key processes that are normally activated by positive emotions. Pride, for example, might be modeled according to a so-called broadening point of view on emotions (Fredrickson, 2000, 2001, 2002). That is, positive feelings broaden a person's momentary thought-action repertoires by widening the array of thoughts and actions that come to mind in any situation. This promotes cognitive flexibility and helps the "I" to overstep social inhibitions or habitual modes of thinking and acting. More specifically, broadening effects of positive emotions are motivational consequences on people's domain specific thoughts and behaviors (Skinner 1999). In Study 1, we focus on the broadening effects of pride on both in- and extra-role performance of salespeople:

a) First, pride stimulates a person to expand his/her cognitive repertoire. The broadening effects that are triggered by positive emotions have been demonstrated to stimulate flexibility, receptivity, and creativity in thinking (e.g., Isen, Daubman, and Nowicki 1987; Kahn and Isen 1993; Estrada, Isen, and Young 1997) as well as facilitate on-going action (Carver and Scheier 1990; Clore 1994). In addition, Fredrickson argues that positive feelings increase optimism (Fredrickson and Branigan 2001). For the sales domain, such motivational constructs are manifest as sales-specific selfefficacy, ability to work hard and sustain effort, and ability to engage in adaptive selling, which 
reflects receptivity and flexibility in salesperson-customer interactions (e.g., Spiro and Weitz 1990; Sujan, Weitz, and Kumar 1994).

b) The broadening tendency triggered by pride also stimulates prosocial behavior. Research shows that individuals with positive versus negative, and on occasion even neutral, feelings engage in altruistic and other helping behaviors (Clark and Isen 1982; Isen and Simmonds 1978; Schaller and Cialdini 1990). Within work settings, altruistic behaviors are embodied in organizational citizenship behaviors (Organ and Payne 1999; MacKenzie, Podsakoff, and Fetter 1991; Podsakoff and MacKenzie 1994).

We thus propose the following hypotheses on the effects of pride:

Hypothesis 1: Pride increases adaptive selling, working hard, and self-efficacy.

Hypothesis 2: Pride increases organizational citizenship behaviors.

\section{Study 1 method}

We distributed questionnaires to 93 sales managers attending a seminar on selling technologies. The salespersons sold financial products to small business. All persons in the seminar responded, and all items were completed. The sample consisted of $73 \%$ male and $27 \%$ female salespersons. A total of $19 \%$ of the participants were younger than 30 years old, $53 \%$ were aged between 30 and 40 years, $16 \%$ between 41 and 50, and 12\% were older than 50 years. Only $15 \%$ worked less than 2 years with their company, the majority (about 50\%) had been between 2 and 6 years in their firm, and another $35 \%$ were more than 6 years with their company. In terms of education, $76 \%$ had a university degree, the rest the equivalent of a high school or vocational education.

Scenarios were used to study the effects of pride, because we wished to learn how salespeople respond to emotion-inducing encounters, but it is unethical to directly manipulate the emotions of participants. Our approach followed contemporary practice in psychology, whereby emotions are 
indirectly induced by asking respondents to put themselves in the place of a protagonist in a vignette, wherein pride and hubris are manipulated (e.g., Roseman 1991; Smith and Lazarus 1993). Some researchers have criticized the use of vignette methodologies, suggesting that a respondent's implicit beliefs about emotions bias their reporting of their own emotions (e.g., Parkinson and Manstead 1992; 1993). However, recent research shows that direct manipulation and scenario methods actually produce converging results for the measurement of emotions (e.g., Robinson and Clore 2001). In the pride-inducing vignette, we asked salespeople to imagine that they had performed very well. They were praised by their manager, their colleagues applauded them, and their excellent performance was printed in the organization's newsletter that is also sent to all customers. In so doing, we followed the suggestions of researchers who have found that felt pride is especially strong when others are copresent or aware of one's accomplishments (Meindl, Ehrlich, and Dukerich 1985; Kroll, Toombs, and Wright 2000). Summaries of the vignette and questions are presented in Appendix 1. Table 2 shows that all measures achieved satisfactory reliabilities.

To develop measures of pride, we began by inspecting definitions and research in the existing psychology literature (Lewis 2000; Tangney 1990; 1999; Ruth, Brunel, and Otnes 2002). Most authors capture emotions by measuring the cognitive activities comprising the emotional content of these states and one's subjective experience (see Bagozzi, Gopinath, and Nyer 1999). We therefore conceived of pride as a syndrome consisting of (1) cognitions associated with pride, i.e., pride creates positive expectations for the person experiencing it, measured by 3 items (e.g., "Now I know quite well what I have to do to be a good salesperson"), and (2) related subjective experiences, measured with 3 items (e.g., "I feel exuberant and exhilarated").

In-role performance is closely linked to motivation. For the case of sales performance, prior research in marketing has demonstrated the positive impact on sales of adaptive selling, working hard, and self-efficacy as motivational variables (e.g., Goolsby et al. 1992; Lambert, Marmorstein, and Sharma 1990; Spiro and Weitz 1990; Sujan 1986; Sujan et al. 1994; Szymanski 1988; Szymanski and 
Churchill 1990). Scales for measuring the three motivational variables were adapted from Spiro and Weitz (1990) and Sujan et al. (1994). Adaptive selling captures the ability of salespersons to adapt their sales techniques to the particular customer at hand and is measured by 8 items (e.g., "I can easily use a wide variety of selling approaches"). Working hard refers to the persistence and amount of work invested by salespeople and consists of 3 items (e.g., "I work untiringly at selling to a customer until I get an order"). Finally, self-efficacy is a sales domain-specific form of self-confidence and 7 items are used to measure it (e.g., "It is difficult for me to put pressure on a customer").

Finally, measures of extra-role performance were adapted from MacKenzie et al. (1991) and include: (1) helping, measured by 3 items (e.g., "I help colleagues who have heavy work loads"), (2) sportsmanship, measured with 4 items (e.g., "I always look on the bright side of the matter"), (3) civic virtue, measured with 3 items (e.g., "I suggest improvements for procedures and practices of the company"), and (4) courtesy, measured by 4 items (e.g., "I consider the impact of my actions on others").

[Place Table 2 about here]

To assess convergent and discriminant validities of the scales used in Study 1, we used confirmatory factor analyses (CFA). Satisfactory model fits are indicated by non-significant chisquare tests, RMSEA values less than .08 and CFI values greater than or equal to .90 . Discussions of indices can be found in Bentler (1990), Browne and Cudeck (1993), and Marsh, Balla, and Hau (1996). Because we used 38 items as measures, we combined these into parcels of 2 items each so as to yield two to four indicators for each latent variable. This meant that we used a type of "partial disaggregation" model for our test of the CFA, as recommended by Bagozzi and Edwards (1998), to yield a satisfactory ratio of sample size to parameters to be estimated.

\section{Study 1 results}

Confirmatory factor analysis. The results of the CFA confirm the stability and validity of the scales used in Study 1. The overall fit is $\chi^{2}(124)=142.23(\underline{p}=.13), C F I=.97$, and RMSEA $=.04$. The 
factor loadings were consistently high for pride (.68 to .76), adaptive selling (.74 to.88), working hard (.72 and .95$)$, self-efficacy (.61 to .71), civic virtue (.68 to .81), sportsmanship (.78 to .94), helping (.73 to .97$)$, and courtesy (.79 to .88$)$, demonstrating good convergent validity. The intercorrelations among the factors are low to moderately high (ranging from -.08 to .66), suggesting that discriminant validity has been achieved as well.

Test of hypotheses. We ran sets of hierarchical regressions with pride experience as the independent variable, and the performance-related motivations, as well as citizenship behaviors, as dependent variables. In the first step, we included only salespeople's pride as an independent variable. In the second step, we added work experience, age, and education as additional variables to take into consideration and control for salespeople's personal backgrounds. Since education was only measured on an ordinal level, we split the sample in two groups, namely high education (college or university degree) versus low education (lower than college degree), thus creating a dichotomous variable to be included in the regressions. The findings of the regression analyses are presented in Table 3. [Place Table 3 about here]

As can be seen in the top panel of Table 3, pride has a significant positive effect on in-role performance, as hypothesized. The size of the effect ranges from high (adaptive selling and selfefficacy) to medium (working hard), resulting in explained variances between 7 and 31 percent. Salespeople experiencing pride thus show more adaptive sales behaviors, work harder, and develop higher feelings of self-efficacy. Inclusion of the demographic variables did not increase the explanatory value of the independent variables, nor did it reduce the effect size of pride on the dependent variables significantly. Hypothesis 1 is therefore substantiated.

Looking next at the bottom panel of Table 3, we see that pride also has a significant positive effect on engagement in organizational citizenship behaviors, as hypothesized. Again, entering the demographic variables in a second step did not change the effect of pride on organizational citizenship behaviors significantly: the stronger a salesperson experiences pride, the stronger s/he shows civic 
virtue, courtesy, and helping. In addition, we found that age has a significant effect on civic virtue behaviors, whereas a high education level significantly increased helping and courtesy. However, contrary to hypothesis, pride fails to influence sportsmanship, i.e. salespeople's complaints about their companies are not reduced by felt pride.

Social desirability. Respondents also completed a selection of 7 items from the MarloweCrowne Social Desirability Scale. Social desirability was not significantly correlated with the pride scale or with the demographical variables, nor was it correlated with the performance-related motivation scales. Social desirability, however, was moderately and positively correlated with the four organizational citizenship behavior scales (ranging from $\mathrm{r}=.20$ to $\mathrm{r}=.32$ ). Including social desirability in the regressions, however, did not change the size or significance level of the effects of pride on the dependent variables, nor did it change the significance of any of the other independent variables.

\section{Study 1 discussion}

One objective of this paper was to study how salespeople experience and profit from pride (a positive self-conscious emotion). Fredrickson (e.g., 2001, 2002) conjectured in her broadening model that such effects should occur for positive emotions, but she did not test pride, and the emotions she did investigate were tested experimentally with students. Seligman (2002) also calls for more research on the effects of positive emotions. Tangney (1999, p. 560) notes further that "pride remains an area wide open for empirical research". Our study shows that pride has pervasive effects across a range of performance outcomes. First, pride stimulates in-role performance-related motivations, specifically a salesperson's ability to use adaptive selling strategies, work hard, and feel self-efficacious. These are probably the effects that most managers have in mind and aim for when praising their employees.

Second, pride stimulates extra-role performance in the form of organizational citizenship behaviors. The reasons here are probably twofold. On the one hand, pride might directly stimulate citizenship behaviors. As the broadening model of positive emotions posits (e.g., Fredrickson and Branigan 2001), positive emotions trigger non-selfish and altruistic urges. On the other hand, felt pride might 
lead a salesperson to consider the costs that the public expression of pride might bring. Here a salesperson takes into account the effects of felt pride stemming from the relationships with customers on the relationships with colleagues. Katz (1999) terms such spill-over effects, trans-situational concerns. Thus, when salespeople experience pride in the field, they feel elated and superior, yet at the same time, they might come to feel that they should strengthen relationships with colleagues so as not to stand out too much and make co-workers feel uncomfortable. Performing extra-role behaviors are a form of such compensatory processes. In this regard, Diener, Lucas, and Oishi (2002) speak about a dialectic function for emotions.

Although our findings support this idea, the hypothesis was not confirmed for sportsmanship. A possible explanation here might be that sportsmanship (i.e. the endurance of inconveniences without complaining, Organ 1988) is not directly related to other people's goodwill. At least to some degree, complaining is tolerated as part of many organizational cultures because it links people with each other and gives them the opportunity to find common topics for conversation and sharing, thus facilitating interactions and the development of affect-based trust (e.g., Coleman 1957; Granovetter 1973; McAllister 1995) and relational social capital (Nahapiet and Ghoshal 1998).

In sum, Study 1 shows that pride facilitates goal striving and has adaptive consequences for salespeople. Next, we consider the self-regulatory processes that occur between the experience of pride and performance outcomes.

\section{STUDY 2. THE ABILITY OF SALESPEOPLE TO SELF-CONTROL PRIDE}

In Study 2 we take a closer look at the dynamics of felt pride. Specifically, we explore how salespeople self-manage their expressions of pride to advantage.

Pride in everyday life has been studied extensively by psychologists Lewis (2000) and Tangney (1999). Lewis (2000) differentiates hubris from positive pride. Tangney and Fischer (1995, p. 512-513) term these beta and alpha pride, respectively. Hubris and positive pride share the same attributional configuration. Both are triggered by positive support from others, and both reflect an internal attribution and a consequent expectation or hope to continue the activities that have been 
reinforced. However, in the case of hubris, the attribution is primarily to one's global self (e.g., "I $\underline{\text { am }}$ a superior person"), while in the case of positive pride, the attribution is primarily to one's behavior or outcomes (e.g., "I performed well"). Baumeister, Boden, and Smart (1996) note that hubris is a socially destructive emotion because it makes people egotistic and arrogant and, as a consequence, they might become envied, shunned, and avoided by others who might even look for retribution (Kroll, Toombs, and Wright 2000; Lewis 2000). Hubristic people also tend to be over-confident and take irrational, overly risky decisions (Hayward and Hambrick 1997; Kroll, Toombs, and Wright 2000). In this regard, positive evaluations by managers that were originally intended to elicit pride in their salespeople might -- when attributed to one's global self instead of one's achievements -- result in hubris and the related negative reactions instead of positive pride.

According to emotion theorists (e.g., Lazarus 1991; Oatley 1992), pride and hubris arise from cognitive appraisals, have a phenomenological tone, are accompanied by physiological processes, are often expressed physically, and result in specific actions to affirm or cope with them. The attributional configuration in hubris produces specific self-categorizations: the salesperson might say, "See, I always knew I was an excellent salesperson"; and in the case of positive pride, a salesperson might say, "Now I feel confident that I can accomplish those tasks." Such self-categorizations are subjectively experienced through positive, pleasant subjective feelings/sensations (see Bagozzi, Gopinath, and Nyer 1999), such as "I feel proud". Further, and as a consequence of selfcategorizations and exuberant feelings, the salesperson will experience such action tendencies as an "urge to tell my friends how well I am doing". We now study whether these three components of pride can be modeled according to speculations made by Fischer and Tangney $(1995$, p. 7$)$ on parallel processes. As shown in Figure 1, (pleasant) subjective experiences (e.g., exhilaration) and action tendencies are parallel outcomes of appraisal processes, and action tendencies in turn produce negative self conscious emotions (e.g., shame, regret) and fear. Shame, regret, and fear function as both anticipated and post-outcome processes to alter one's future emotional reactions. In this sense, they are important aspects of self-regulation. Note that the relationships shown in Figure 1 apply separately for hubris and pride (see Figure 2).

[Place Figure 1 about here] 
Based upon the arguments developed so far, we state two propositions:

Proposition 1: Hubris occurs when a salesperson attributes achievements to his/her total self, and this appraisal leads to feelings of euphoria (subjective experiences), which in turn give rise to the display of the emotion to colleagues and customers.

Proposition 2: Pride occurs when a person attributes achievement to his/her own behaviors, or outcomes, and this appraisal leads to feelings of euphoria (subjective experiences), which in turn give rise to the display of the emotion to colleagues and customers.

Given that salespeople appraise their own displays of pride and hubris, we study whether these appraisals also feedback on the expressions of pride and hubris. Psychologists call the ability to selfregulate emotions, response-focused modulation (Gross 1999) or emotional dissemblance (i.e., putting communicative intent into one's emotions, Saarni 1999). With Figure 1 being a general model for the unfolding of salespeople's emotions, we expect to find particular pathways for pride and hubris as specified in Hypotheses 3-6 below.

As Fischer and Tangney (1995, p. 10) point out, "if pride is too extreme or too public, it becomes shameful, and then the shame self-control comes into play." Similarly, Lazarus and Lazarus (1994, p. 103) note, "pride has competitive, and sometimes moral overtones. We cope with it by walking a fine line between justifiable pride and overweening pride (hubris), which could lead to social criticism." Will salespeople engage in self-control when they express pride and hubris? Spiro and Weitz (1990) and Sujan (1999) propose that salespeople should be adaptive with their cognitive and emotional expressions during customer contact, if they want to succeed. Similarly, Soldow and Thomas (1984) propose that salespeople prefer to take a stance of deference to prevent provoking competitive feelings in customers. Therefore, when salespeople interact with customers they have reason to dampen the expression of their pride and hubris. The dampening will occur in response to anticipated feelings of shame, regret, and fear, where these latter feelings function as meta-emotions (note: shame and regret as negative self-conscious emotions and fear of retribution are discussed below). But will salespeople also dampen their display of pride and hubris in front of colleagues? We believe that salespeople will have less reason to dampen their expressions of pride toward colleagues because displays of pride draw positive attention from colleagues and enhance salespeople's 
reputation and ultimately strengthen social capital within the firm. Expressions of pride elicit complementary and reciprocal emotions (e.g., sympathy and admiration) and behaviors (e.g., eagerness to team up with successful or assertive persons) (Keltner and Haidt 1999; Clark and Brissette 2000). Salespeople will, however, seek to dampen their expression of hubris towards colleagues because it makes them appear egotistic and arrogant (Baumeister, Boden, and Smart 1996) and, as a consequence, they might become envied, shunned, and avoided by others who might even look for retribution (Kroll, Toombs, and Wright 2000; Lewis 2000). Hence, we hypothesize:

Hypothesis 3: Salespeople will dampen the expression of hubris (i.e., feel anticipated regret and fear) towards customers and colleagues.

Hypothesis 4: Salespeople will dampen the expression of pride (i.e., feel anticipated regret and fear) towards customers but not towards colleagues.

We suggested that salespeople will engage in self-control when they display their emotions to different members of their role-set, especially customers. To the extent that salespeople are aware of possible negative consequences, we might expect them to experience certain emotions designed to regulate the negative effects of pride and hubris. Fischer and Tangney (1995) call these metaemotions, and Salovey et al. (2000) propose that meta-emotions help people self-regulate their emotions.

To understand what meta-emotions are and how they operate, it is useful to construe emotions as processes extended in time (e.g., Fischer and Tangney 1995; Frijda, Manstead, and Bem 2000). The emergence of any particular emotional reaction is often followed by one or more other emotions that function to help the person experiencing the original emotion adapt to it. In a sense, the original emotion is transformed into one or more other emotions, which serve to regulate the original emotion. The transformation occurs as a result of self-appraisals of the meaning of the original emotion and self-monitoring of one's action tendencies that follow (Fischer and Tangney 1995, p. 9; Thoits 1990, p. 184). For instance, the development of pride is often followed by a sense of anxiety: "Sometimes it scares me when I feel arrogant and brag after things go really well."

When salespeople experience hubris and pride, what meta-emotions follow? Exline and Lobel (1999) show that when people outperform colleagues (or friends), "striving for dominance might clash 
with their affiliative feelings" (p. 310) and people develop mixed emotions (p. 312). Kitayama, Markus, and Matsumoto (1995) and Fischer and Tangney (1995) note that such reactions lead to dialectic feelings. For instance, after displaying pride, people tend to feel some shame and then may develop anger towards those who have provoked their shame. We propose that two groups of metaemotions are central in the self-regulation of pride and hubris. First, because people who witness excessive pride in others may be envious and even feel destructive if given the chance, salespeople might become fearful of retribution. Second, salespeople might conclude that their open expression of pride and hubris in front of others violates norms and feel shame and regret (i.e. negative self-

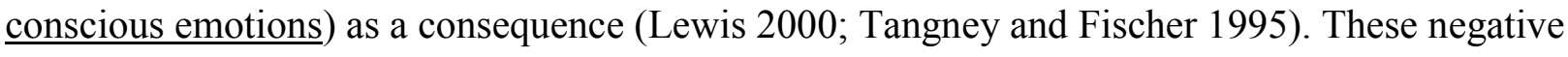
emotions act as regulators of pride by lowering its felt physiology and action tendencies (Fredrickson and Levenson 1998; Fredrickson et al. 2000).

Another question is whether fear and negative SC-emotions occur more readily or strongly in front of customers than in front of colleagues. We expect so. An important goal of many salespeople is to develop long-term relationships with customers because they depend on their customers for their livelihood. But long-term relationships can be damaged if a salesperson displays hubris, and knowledge of this possibility can produce regret after one displays hubris in front of his/her customers. Similarly, might negative SC-emotions ensue after the display of pride or hubris in front of colleagues? We believe that salespeople will feel ashamed and regret having expressed hubris in front of colleagues, but not pride. By showing hubris, salespeople know that they may lose social capital. The drawbacks with arousing envy and making enemies in one's own organization should lead to anticipated negative SC-emotions and fear, so as to suppress hubris. Pride, on the other hand, is a positive SC-emotion that reveals one's self-confidence to reach goals, and given the fact that people with pride obtain a certain degree of attention getting power from colleagues, displays of pride might become functional. Therefore, salespeople should be less likely to develop negative SCemotions after expressing pride in front of colleagues than in front of customers. We thus hypothesize: Hypothesis 5: Salespeople will develop negative SC-emotions and fear as a consequence of displaying hubris in front of customers and colleagues.

Hypothesis 6: Salespeople will develop negative SC-emotions and fear as a result of 
displaying pride in front of customers but not in front of colleagues.

\section{Study 2 method}

A total of 780 questionnaires were sent to salespeople who worked in two automotive dealerships. Two hundred and fifty salespeople returned the questionnaires for a $32 \%$ response rate. In exchange for their participation they received a gift worth $\$ 12$. The sample can be described as follows: a majority (about $78 \%$ ) of the salespeople were men, about $34 \%$ of the salespeople were younger than 30 years old, 39\% were between 30 and 40, 13\% between 41 and 50, and 14\% was older than 50 . With respect to experience, about $24 \%$ of the sample had been with the organization less than 2 years, $51 \%$ had been with the firm between 2 and 6 years, and $25 \%$ were with the company between 6 and 20 years. Finally, most salespeople had finished basic and advanced vocational studies. Only 4 $\%$ had a university or college degree, which is typical for automotive salespeople.

The questionnaire can be found in Appendix 2. Table 4 presents means, standard deviations, and alphas, and Table 5 shows the correlation matrix of constructs. Salespeople simultaneously develop pride in the actions they take and outcomes they achieve, on the one hand, and in their global self ("being a good salesperson"), on the other hand. Whereas in Study 1, salespeople responded only to questions about pride, in Study 2, all salespeople were exposed to the scenario twice, measuring both the development of pride, and the development of hubris. Questionnaires were printed in different versions such that they either started with the questions referring to pride first, followed by those referring to hubris, or began with the questions for hubris first, followed by those for pride.

Drawing upon the literature on appraisal themes of pride and hubris (Lewis 2000; Tangney 1999; see also Bagozzi, Gopinath, and Nyer 1999; Ruth, Brunel, and Otnes 2002) and the descriptions of the emotional process in the psychological literature (e.g., Lazarus 1991; Oatley 1992), we developed a questionnaire for hubris consisting of (1) cognitive appraisals, measured with 3 items (e.g., "I think I am a top salesperson"), (2) related subjective experiences, measured by 3 items (e.g., "I feel invincible"), (3) action tendencies towards both customers and colleagues, where each was measured by 2 items (e.g., "I feel an urge to tell colleagues (customers) I am doing well”), (4) negative self-conscious emotions in front of both colleagues and customers, where each was measured by 2 items (e.g., "I feel ashamed that I could not contain my pride to colleagues (customers)", and (5) 
fear towards both colleagues and customers, where each was measured with 3 items (e.g., "I think my colleagues (customers) will gossip that I am a big-headed person"). Pride was conceived in a parallel manner to hubris, except that the cognitive appraisals included such items as, "Now I know quite well what I have to do to be a good salesperson."

[Place Table 4 and Table 5 about here]

Scenarios were used as a basis to study the effects of hubris and pride. People were exposed to the scenarios and asked to put themselves in the place of a salesperson who performed relatively well and under conditions where customers and people in their own organization became aware of this and praised them.

To perform confirmatory factor analyses and test hypotheses, LISREL8 was used (Jöreskog and Sörbom 1996). The goodness of fit of the models were assessed with chi-square tests, the RMSEA, and the CFI (Bentler 1990; Browne and Cudeck 1993; Marsh et al. 1996).

\section{Study 2 results}

Confirmatory factor analysis. The results of the CFA performed on the measures of pride and hubris, respectively, confirmed reasonable discriminant and convergent validity of the scales for each of the two types of pride. Both measurements models fit the data satisfactorily: for hubris, $\chi^{2}(142)=$ $469.82, \underline{\mathrm{p}} \underset{=}{\sim} .00, \mathrm{RMSEA}=.10, \mathrm{CFI}=.90$; for positive pride, $\chi^{2}(142)=433.03, \underline{\mathrm{p}} \simeq .00, \mathrm{RMSEA}=$ $.09, \mathrm{CFI}=.91$. The factor loadings of all factors are consistently high: cognitive appraisals (hubris: .79 to .87 ; positive pride: .61 to .84 ), subjective experiences (hubris: .70 to .87 ; positive pride: .74 to .89 ), action tendencies toward customers (hubris: .82 and .92; positive pride: .85 and .89 ), action tendencies toward colleagues (hubris: .85 and .88; positive pride: .84 and .90 ), negative SC-emotions for customers (hubris: .88 and .90; positive pride: .86 and .97), fear for customers (hubris: .79 to .95; positive pride: .78 to .96 ), negative SC-emotions for colleagues (hubris: .86 to .87; positive pride: .79 and .90), and fear for colleagues (hubris: .70 to .95 ; positive pride: .76 to .95 ). The interfactor correlations range from .03 to .79 for hubris, and from -. 10 to .80 for positive pride.

Test of hypotheses. Figure 2 presents the findings for tests of Hypotheses 3-6. The overall model fit the data well: $\chi^{2}(\mathrm{df}=8, \underline{\mathrm{N}}=221)=6.11, \underline{\mathrm{p}} \sim .64, \mathrm{RMSEA}=.00$, and CFI $=1.00$. Notice that, in both the cases of hubris and pride, the general flow of effects is from cognitive appraisals to 
both physiological awareness and felt action tendencies. Thus, the data are consistent with Propositions 1 and 2. Note also that cognitive appraisals under hubris and pride correlate at a relatively low level $(\phi=.42)$, thereby suggesting that discriminant validity has been achieved.

[Place Table 6 and Figure 2 about here]

Looking first at the findings for Hypotheses 3 and 4, we see that, for both hubris and pride, subjective experiences dampen action tendencies toward customers, as hypothesized (see Figure 2). Also, for pride, subjective experiences do not dampen action tendencies toward colleagues, as proposed. But for hubris, subjective experiences did not dampen action tendencies toward colleagues, contrary to expectations. We turn next to the self-regulatory reactions of negative SC-emotions and fear in response to felt action tendencies as proposed in Hypotheses 5 and 6 (note that tests of direct paths from cognitive appraisals and subjective experiences to both negative SC-emotions and fear showed that these paths were non-significant; thus action tendencies fully mediate the effects of appraisals and subjective experiences). For hubris, we discover that action tendencies toward customers influence both negative SC-emotions and fear, as hypothesized, and action tendencies towards colleagues influence fear but not negative SC-emotions, also as forecast. For pride, action tendencies toward customers affect negative SC-emotions and fear, but action tendencies toward colleagues fail to affect negative SC-emotions and fear, as predicted.

Finally, we wish to test the relative strength of paths between hubris and pride and within hubris and pride. Although not having specific hypotheses here, we want to discover whether the emotional processes unfold similarly for positive pride and hubris or show distinctive emotionspecific features. First, we tested whether the path from cognitive appraisal to subjective experiences is larger under pride than hubris (see Figure 2). This was indeed sustained $\left(\chi_{d}^{2}(1)=9.99, \underline{p}<.01\right)$. Second, the following paths do not differ between hubris and pride: subjective experiences $\rightarrow$ action tendencies towards customers $\left(\chi_{\mathrm{d}}^{2}(1)=.01, \mathrm{~ns}\right)$, action tendencies toward colleagues $\rightarrow$ fear $\left(\chi_{\mathrm{d}}^{2}(1)\right.$ $=.31, \mathrm{~ns})$, action tendencies towards customers $\rightarrow$ negative SC-emotions $\left(\chi_{\mathrm{d}}^{2}(1)=.31\right.$, ns), and action tendencies toward customers $\rightarrow$ fear $\left(\chi_{\mathrm{d}}^{2}(1)=.57, \mathrm{~ns}\right)$.

\section{Study 2 discussion}


Study 1 demonstrated the effects of felt pride, but in Study 2 we looked deeper into how pride is self-managed in what might be termed, the emotional system. The emotional system is built upon four different components: cognitive appraisals, subjective experiences, action tendencies (towards customers and colleagues), and subsequent meta-emotion responses (i.e., negative SC-emotions and fear). These components of the emotion systems operate in parallel, but hubris and pride each constitute a specific emotion system configuration. Hubris and pride unfolded in a way that is largely consistent with the propositions by Fischer and Tangney (1995) and as presented in Figure 1. Yet, hubris and pride also show some emotion-specific features that suggest a reformulation of the process for self-regulation as offered in Figure 2 and described as follows. For hubris, appraisals produce subjective emotional experiences, as well as felt action tendencies, towards colleagues and customers. For positive pride, appraisals also produce subjective experiences, but only action tendencies towards customers. In addition, cognitive appraisals in the case of pride more strongly provoke subjective experiences than in the case of hubris. We interpret this configuration of the emotional system as an indication that hubris creates a fuzzier emotional pathway than pride. Such an interpretation is consistent with Lewis' (2000, p. 628) observation that, when the total self is involved in a selfconscious emotion, "The self becomes embroiled in the self. It becomes embroiled because the evaluation of the self by the self is total. There is no way out... There is little wonder that in using such global attribution one can think of nothing else, and one becomes confused...."

Consistent with the literature on emotions (Fischer and Tangney 1995; Katz 1999; Kitayama, Markus, and Matsumoto 1995), we conceived of pride as a relatively long-term emotion that is intimately connected with meta-emotions (fear and negative SC-emotions), and the meta-emotions feedback to modulate the way in which salespeople express pride. As Fischer and Tangney (1995) note, people not only experience positive emotions like pride, but they also evaluate and appraise the expression of those emotions. What was apparent in our study is that salespeople are keen to appraise the negative consequences of their pride and hubris in front of customers, but to a lesser extent 
towards colleagues. This is consistent with the view that salespeople's most important concern is their long-term relationship with customers, and in order to secure these relationships, they endure some fear and negative SC-emotions. Fear and negative SC-emotions ought to be conceived as emotionalbased sensors that signal that overt expressions of pride and hubris might backfire.

The findings imply that meta-emotions can be conceived as signposts buffering the expression of pride. Indeed, fear and negative SC-emotions in response to expressed pride made salespeople inhibit their overt expressions of pride and hubris in relation to customers. This then shows the paradoxical nature of pride. Salespeople are energized by pride and hubris, but they also control the expression of pride and hubris in order to secure long-term relationships with customers because they fear, among other things, that customers might respond negatively to their pride and hubris.

With colleagues, however, salespeople did not reduce their expressions of hubris and pride. Apparently, by expressing pride and hubris towards colleagues, salespeople signal to these significant others that they match the expectations of the firm and their colleagues. We interpret this in two ways. First, salespeople express to others their fundamental need to belong (Baumeister and Leary 1995) -specifically they signal that they match the norms and expectations of their specific reference group -but they also seek to attract and hold attention. That is, they also signal a sense of superiority or self puffery within their social group (Gilbert 1990). We believe that pride is an important social emotion because it gives salespeople confidence in themselves, allowing them to remain assertive across different members of their role-set (e.g., Parkinson 1995; Fredrickson and Branigan 2001). When salespeople feel confident, they posses an emotional resource "that allows relationships to be defined and maintained..." (Waldron 2000, p. 73). Salesperson's self-confidence in other words may have positive and even contagious effects on different members of their role set.

\section{GENERAL DISCUSSION}

This study looked at pride within a selling environment and conceived of it as a positive SCemotion that originates in salespeople's response to positive judgments by significant others within 
their role-set. The results of our first study show that pride possesses broadening characteristics (e.g., Fredrickson 2002). Pride increases performance-related motivations, specifically a salesperson's selfefficacy as well as the willingness to adapt one's selling strategies and to work harder. Secondly, pride stimulates salespeople to engage in organizational citizenship behaviors. In our second study, we more closely investigated how pride functions by differentiating between alpha pride (hubris) and beta pride (positive pride) and scrutinizing the emotional systems involved in these two types of pride; both emotions were similar, yet emerged from two different appraisal processes. We especially were interested in how salespeople manage their pride and hubris, and we found that fear and negative SCemotions have a positive effect on salespeople's behavior in that these emotions press salespeople to self-control their pride and hubris.

Now that we have shown that pride is an emotion that has positive effects and also is an emotion that is self-regulated by salespeople, one might question whether pride can be influenced by management as a strategic tool. To be clear, we do not recommend that managers instill hubris. If emotions function according to specific paths -- in our case, pride emerges due to the fact that a person is capable of matching significant others' expectations and because others overtly express their approval -- then managers can use this knowledge as a managerial tool (e.g., Elster 1999).

Six points can be made in this regard. First, because pride results from positive or negative evaluations from significant others, instilling pride is a fruitful management tool. While pride might occur when salespeople succeed at a difficult task (Weiner 1992), it can also be triggered through task accomplishment that conforms to what significant others expect (Tangney 1990; 1999). The latter possibility provides interesting implications for managers on how to reward and motivate their employees by openly and strategically praising them. By instilling pride, managers can motivate employees to engage in what might not be very difficult, per se, but what is nevertheless necessary to accomplish within the organization. Not surprisingly as Katzenbach and Santamaria (1998) point out, pride can be an important strategy to motivate employees for service firms that involve repetitive 
actions. In this regard, Brown and Peterson (1993) suggest that salespeople not only should receive honor for excellent performance but also for their efforts along the way.

Second, there is a dark side related to efforts at instilling pride. By instilling pride, managers may contribute to hubris in salespeople (even though the data in this paper show that hubris can be well contained), if the salespersons attribute achievements too much to their total selves as opposed to their actions. We suspect that some salespeople with specific personality traits might be prone to develop hubris as opposed to pride (e.g., Lewis 2000). Likewise, when salespeople who are already committed to the organization discover that they cannot reach the expectations of their managers, this might damage one's self and lead to destructive behavior or job withdrawal (Baumeister, Boden, and Smart 1996).

Third, the results of our study show that when salespeople self-regulate their pride they in fact "flow with their pride". Pride energizes them (broadening effects), yet salespeople also dampen their expression of pride so as to avoid negative effects (development of fear and negative meta-emotions). This ability to ride with the flow has similarities with previous findings. Singh, Goolsby, and Rhoads (1994) and Singh (1996) show that salespeople need a certain amount of stress to perform well but too much stress has negative effects on performance. Singh and colleagues suggest that the secret of working in stressful environments is to cope with stress at the right time. Pride seems to function in a parallel way.

Fourth, when praising their salespeople, managers might at times want to mention the possible negative social consequences of expressing pride. By doing so, they can try to stimulate fear and anticipation of shame and regret about showing pride. These meta-emotions help salespeople regulate their pride experiences and keep them within socially acceptable limits. In this regard, salespeople engage in emotional labor (e.g., Ashforth and Humphrey 1993; Morris and Feldman 1996), they use fear and negative meta-emotions (shame and regret) to facilitate the dissemblance of the experience of pride on the one hand, and its expression on the other hand. In doing this, salespeople are able to 
profit from the positive consequences of experiencing pride and, at the same time, escape the negative social consequences of expressing pride.

Fifth, over the years, we have had the opportunity to discuss our research with managers and salespeople. We learned that salespeople sometimes feel a bit uncomfortable with expressions of pride, especially when management attempts to instill pride. This is surprising for two reasons. First, pride was one of the two most frequently and intensely felt emotions in our prestudy, and second, as Kitayama, Markus, and Matsumoto (1995) suggest within Western cultures, pride is the dominant emotion. So why should salespeople feel uncomfortable with their feelings of pride? For our sample of Dutch salespeople, it is possible that a common cultural prohibition against showing pride creates a built-in suppression of it. Such prohibitions are typical of the Protestant Work Ethic, which pervades the Netherlands (Hofstede 2001).

Finally, by instilling pride, managers should always communicate to their salespeople that although it is good to feel proud, pride should be displayed carefully, especially with customers. Our study shows that meta-emotions aid salespeople in managing the expression of pride, but managers should also coach and train salespeople on how to become more emotionally intelligent (e.g., Salovey et al. 2000). Emotional intelligence implies the ability to understand how expressions of one's own emotions affect other people. Training programs based on role-playing during the experience of emotional episodes of pride could help salespeople develop the proper balance between showing healthy levels of self-assurance on the one hand and avoiding the appearance of arrogance on the other hand.

\section{FUTURE RESEARCH}

Although our findings indicate that salespeople manage the expression of their emotions, it is possible to study in even greater depth how salespeople specifically control their emotions (e.g., Gross 1999). For instance, one could develop an emotional coping style scale in order to estimate the degree to which salespeople manage the development of their pride feelings as well as the expression of their 
pride as a disposition.

In our samples, we could not distinguish gender effects because of the dearth of female sales representatives. There is some evidence in the literature that males and females experience and cope differentially with emotions (Brody 1999). Gender differences need to be explored in the future.

Similarly, it can be assumed that non-emotional dispositions play an important role in experiencing certain emotions (e.g., Smith et al. 1999). Some researchers, for instance, argue that pride arises from a need to belong to an organization or subgroup within it and also points to a willingness to define one's worth to the extent that one receives recognition from the organization and its members (Baumeister and Leary 1995). However, this proposition should be tested formally. Such a research project could investigate whether salespeople who have a substantial need to belong will develop hubris rather than pride. Other personality traits might make a salesperson prone to developing hubris rather than pride and vice versa: chronic self-confidence, self-consciousness, optimism-pessimism, and need for power may be worth investigating in this regard (e.g., Hayward and Hambrick 1997).

Finally, as we move more toward an era of diversity, it could be that different ethnic groups or cultures experience self-conscious emotions (and pride in particular) in different ways, or respond to them differently. Asians, for instance, experience shame more readily than pride (e.g., Kitayama, Markus, and Matsumoto 1995). Cross-cultural research on shame demonstrates that members of Western and Eastern cultures experience this SC-emotion similarly yet have different responses to it, which in turn impact performance differently (e.g., Bagozzi, Verbeke, and Gavino 2003). 


\section{REFERENCES}

Ashforth, Blake E. and Ronald H. Humphrey. 1993. "Emotional Labor in Service Roles: The Influence of Identity.” Academy of Management Review 18 (January): 88-115.

Bagozzi, Richard P. and Jeffrey R. Edwards. 1998. "A General Approach for Representing Constructs in Organizational Research.” Organizational Research Methods 1: 45-87.

Bagozzi, Richard P., Mahesh Gopinath, and Prashanth U. Nyer. 1999. “The Role of Emotions in Marketing.” Journal of the Academy of Marketing Science 27 (Spring): 184-206.

Bagozzi, Richard P., Willem Verbeke, and Jacinto C. Gavino. 2003. "Culture Regulates the Self-

Regulation of Shame and its Effects on Performance: The Case of Salespersons in the

Netherlands and the Philippines.” Journal of Applied Psychology 88 (April): 219-233.

Barret, Karen C. 1995. “A Functionalist Approach to Shame and Guilt.” In Self-Conscious Emotions.

Eds. June P. Tangney and Kurt W. Fischer. New York: Guilford Press, 25-63.

Baumeister, Roy F. and Mark Leary. 1995. “The Need to Belong: Desire for Interpersonal

Attachments as a Fundamental Human Motivation.” Psychological Bulletin 117 (May): 497-529.

Baumeister, Roy F., Laura Smart, and Joseph M. Boden. 1996. "Relation of Threatened Egotism to

Violence and Aggression: The Dark side of High Self-Esteem.” Psychological Review 103

(January): 5-33.

Behrman, Douglas N. and William D. Perreault. 1984. "Measuring the performance of salespersons." Journal of Business Research 10 (September): 355-370.

Bentler, Peter M. 1990. “Comparative Fit Indexes in Structural Models.” Psychological Bulletin 107 (March): 238-246.

Bolino, Mark C. 1999. “Citizenship and Impression Management: Good Soldiers or Good Actors?” Academy of Management Review 24 (January): 82-98.

Brody, Leslie. 1999. Gender, Emotion, and the Family. Cambridge: Harvard University.

Brown, Steven P., William L. Cron, and John W. Slocum. 1997. "Effects of Goal-Directed Emotions 
on Salesperson Volitions, Behavior, and Performance: A Longitudinal Study.” Journal of Marketing 61 (January): 39-50.

Brown, Steven P. and Robert A. Peterson. 1993. "Antecedents and Consequences of Salesperson Job Satisfaction: Meta-Analysis and Assessment of Causal Effects." Journal of Marketing Research 30 (April): 63-77.

Browne, Michael W. and Robert Cudeck. 1993. "Alternative Ways of Assessing Model Fit.” In Testing Structural Equation Models. Eds. Kenneth A. Bollen and Scott J. Long. Newbury Park, CA: Sage, 136-162.

Clark, Margaret S. and Ian Brissette. (2000). "Relationship Beliefs and Emotion: Reciprocal Effects." In Emotions and Beliefs: How Feelings Influence Thoughts. Eds. Nico H. Frijda, Antony S.R. Manstead, and Sacha Bem. Paris: Cambridge University, 212-140.

Clark, Margaret S. and Alice M. Isen. 1982. “Toward Understanding the Relationship Between Feeling States and Social Behavior.” In Cognitive Social Psychology. Eds. A.H. Hastorf and Alice M. Isen. New York: Elsevier, 73-108.

Clore, Gerald L. 1994. "Why Emotions are Felt.” In The Nature of Emotion: Fundamental Questions. Eds. Paul Ekman and Richard J. Davidson. New York: Oxford University, 103-111.

Coleman, James S. 1957. Community Conflict. New York: Free Press.

Diener, Ed, Richard E. Lucas, and Shigehiro Oishi. 2002. "Subjective Well-Being: The Science of Happiness and Life Satisfaction.” In Handbook of Positive Psychology. Eds. C.R. Snyder and Shane J. Lopez. New York, NY: Oxford University, 63-73.

Elster, Jon. 1999. Alchemies of the Mind: Rationality and the Emotions. Cambridge: Cambridge University.

Estrada, Carlos A., Alice M. Isen, and Mark J. Young. 1997. "Positive Affect Facilitates Integration of Information and Decreases Anchoring in Reasoning Among Physicians.” Organizational Behavior and Human Decision Processes 72 (October): 117-135. 
Exline, Julie J. and Marci Lobel. 1999. "The Perils of Outperformance: Sensitivity about Being the Target of a Threatening Upward Comparison.” Psychological Bulletin 3 (May): 307-337.

Feldman, Daniel C. 1976. “A Contingency Theory of Socialization.” Administrative Science

Quarterly 21 (September): 433-452.

Feldman, Daniel C. 1981. “The Multiple Socialization of Organization Members.” Academy of Management Review 6 (April): 309-318.

Fischer, Kurt W. and June P. Tangney. 1995. "Self-Conscious Emotions and the Affect Revolution:

Framework and Overview." In Self-Conscious Emotions. Eds. June P. Tangney and Kurt W.

Fischer. New York: Guilford, 3-24.

Fredrickson, Barbara L. 2000. "Cultivating Positive Emotions to Optimize Health and Well-Being."

Prevention and Treatment 3. Available on the world wide web: http://journals.apa.org/prevention.

Fredrickson, Barbara L. 2001. "The Role of Positive Emotions in Positive Psychology: The Broadenand-Build Theory of Positive Emotions.” American Psychologist 56 (March): 218-226.

Fredrickson, Barbara L. 2002. "Positive emotions.” In Handbook of positive psychology. Eds. C.R.

Snyder and Lopez, Shane J. New York: Oxford University, 120-134.

Fredrickson, Barbara L. and Christine Branigan. 2001. "Positive emotions.” In Emotions: Current Issues and Future Directions. Eds. Tracy J. Mayne and George A. Bonanno. New York: Guilford, $123-151$

Fredrickson, Barbara L. and Levenson, Robert W. 1998. "Positive Emotions Speed Recovery from the Cardiovascular Sequelae of Negative Emotions." Cognition and Emotion 12 (March): 191-220.

Fredrickson, Barbara L., Roberta A. Mancuso, Christine Branigan, and Michele M. Tugade. 2000.

“The Undoing Effect of Positive Emotions.” Motivation and Emotion 24 (December): 237-258.

Frijda, Nico H. 1986. The emotions. London, UK: Cambridge University.

Frijda, Nico H., Antony S. Manstead, and Sacha Bem. 2000. "The Influence of Emotions on Beliefs." In Emotions and Beliefs: How Feelings Influence Thoughts. Eds. Nico H. Frijda, Antony S. 
Manstead and Sacha Bem. Paris: Cambridge University Press, 1-9.

Gilbert, Paul. 1990. “Changes: Rank, Status, and Mood.” In On the Move: The Psychology of Change and Transition. Eds. Shirley Fischer and Cary L. Cooper. New York: Wiley, 33-52.

Goolsby, Jerry R., Rosemary R. Lagace, and Michael L. Boorom. 1992. "Psychological Adaptiveness and Sales Performance.” Journal of Personal Selling and Sales Management 12 (Spring): 51-66. Granovetter, Mark. 1973. “The Strength of Weak Ties.” American Journal of Sociology 78 (May): 1360-1380.

Gross, James J. 1999. “Emotion and Emotion Regulation.” In Handbook of Personality: Theory and Research. Eds. Lawrence A. Pervin and Oliver P. John. New York: Guilford, 525-552.

Harter, Susan. 1999. The construction of the self. New York: The Guilford Press.

Hayward, Mathew L. and Donald C. Hambrick. 1997. "Explaining the Premiums Paid for Large Acquisitions: Evidence of CEO Hubris.” Administrative Science Quarterly 42 (March): 103-127. Hofstede, Geert. 2001. Culture’s Consequences. 2nd ed. Thousand Oaks, CA: Sage. Ibarra, Hermione. 1992. "Structural Alignments, Individual Strategies, and Managerial Action: Elements Towards a Network Theory of Getting Things Done.” In Networks and organization. Eds. Nitin Nohria and Robert G. Eccles. Cambridge, MA: Harvard University Press, 165-188. Isen, Alice M., Kimberly A. Daubman, and Gary P. Nowicki. 1987. "Positive Affect Facilitates Creative Problem Solving.” Journal of Personality and Social Psychology 52 (June): 1122-1131. Isen, Alice M. and Stanley F. Simmonds. 1978. "The Effect of Feeling Good on a Helping Task That is Incompatible With Good Mood.” Social Psychology 41 (December): 345-349.

Jöreskog, Karl G. and Dag Sörbom. 1996. LISREL8 User's reference guide. Chicago, IL: Scientific Software.

Kay Ash, Mary. 1995. You can have it all. Rocklin CA: Prima Publishing.

Kahn, Barbara E. and Alice M. Isen. 1993. "The influence of positive affect on variety seeking among safe, enjoyable products.” Journal of Consumer Research 20 (September): 257-270. 
Katz, Jack. 1999. How Emotions Work. Chicago: University of Chicago.

Katzenbach, Jon R. and Jason A. Santamaria. 1998. "Firing up the Frontline.” Harvard Business

Review 77 (May-June): 107-117.

Keltner, Dacher and Jonathan Haidt. 1999. "Social Functions of Emotions at Four Levels of

Analysis.” Cognition and Emotion 13 (September): 505-521.

Kitayama, Shinobu, Markus, Hazel R., and Hisaya Matsumoto. 1995. "Culture, Self, and Emotions: A

Cultural Perspective on Self-Conscious Emotions.” In Self-Conscious Emotions. Eds. June P.

Tangney and Kurt W. Fischer. New York: Guilford, 439-464.

Kroll, Mark J., Leslie A. Toombs, and Peter Wright. 2000. “Napoleon's Tragic March Home from

Moscow: Lessons in Hubris.” Academy of Management Executive 14 (February): 117-128.

Lambert, Douglas M., Howard Marmorstein, and Arun Sharma. 1990. “The Accuracy of

Salespersons' Perceptions of Their Customers: Conceptual Examination and an Empirical Study."

Journal of Personal Selling and Sales Management 10 (Winter): 1-9.

Lazarus, Richard S. 1991. Emotion and Adaptation. New York, Oxford: Oxford University.

Lazarus, Richard S. and Bernice N. Lazarus. 1994. Passion and Reason. New York: Oxford

University.

Lewis, Michael. 2000. "Self-Conscious Emotions: Embarrassment, Pride, Shame, and Guilt.” In Handbook of Emotions. $2^{\text {nd }}$ edition. Eds. Michael Lewis and J.M. Haviland-Jones. New York: Guilford, 623-636.

MacKenzie, Scott B., Philip M. Podsakoff, and Richard Fetter. 1991. “Organizational Citizenship Behavior and Objective Productivity as Determinants of Managerial Evaluations of Salespersons' Performance.” Organizational Behavior and Human Decisions Processes 50 (October): 123-150. McAllister, Daniel J. 1995. “Affect- and Cognition-Based Trust as Foundations for Interpersonal Cooperation in Organizations.” Academy of Management Journal 38 (February): 24-59.

Marsh, Herbert, John R. Balla, and Kit-Tai Hau. 1996. “An Evaluation of Incremental Fit Indices: A 
Clarification of Mathematical and Empirical Properties.” In Advanced Structural Equation

Modeling: Issues and Techniques. Eds. George A. Marcoulides, and Randall E. Schumacker.

Mahwah, NJ: Erlbaum, 315-353.

Meindl, James R., Sanford B. Ehrlich, and Janet M. Dukerich. 1985. “The Romance of Leadership.” Administrative Science Quarterly 30 (March): 78-102.

Morris, J. Andrew and Daniel C. Feldman. 1996. "The Dimensions, Antecedents, and Consequences of Emotional Labor.” Academy of Management Review, 21 (October): 986-1010.

Morrison, Elizabeth W. 1994. "Role Definitions and Organizational Citizenship Behavior: The Importance of the Employee's Perspective. Academy of Management Journal 37 (December): 1543-1567.

Morrison, Elizabeth W. 1994. "Role Definitions and Organizational Citizenship Behavior: The Importance of the Employee's Perspective." Academy of Management Journal 37 (December): $1543-1567$.

Motowidlo Stephan J. and James R. Van Scotter. 1994. "Evidence that Task Performance Should be Distinguished from Contextual Performance." Journal of Applied Psychology 79 (August): 475480.

Nahapiet, Janine E. and Sumantra Ghoshal. 1998. "Social Capital, Intellectual Capital and the Organizational Advantage.” Academy of Management Review 23 (April): 242-266.

Organ, Dennis W. 1988. Organizational Citizenship Behavior: The Good Soldier Syndrome. Lexington, MA: Lexington Books.

Organ, Dennis W. and Julie B. Paine. 1999. “A New Kind of Performance for Industrial and Organizational Psychology: Recent Contributions to the Study of Organizational Citizenship Behavior." In International Review of Industrial and Organizational Psychology, Vol 14. Eds. Cary L. Cooper and Ivan T. Robertson. New York: Wileys and Sons, 337-368.

Parkinson, Brian. 1995. Ideas and realities of emotion. London and New York: Routledge. 
Parkinson, Brian and Antony S.R. Manstead. 1992. “Appraisal as a Cause of Emotion.” In Review of Personality and Social Psychology, Vol. 13. Ed. Margaret S. Clark. New York: Russell Sage, 122-149.

Parkinson, Brian and Antony S.R. Manstead. 1993. "Making Sense of Emotion in Stories and Social Life.” Cognition and Emotion 7 (May-July): 295-323.

Podsakoff, Philip M. and Scott B. MacKenzie. 1994. "Organizational Citizenship Behaviors and sales unit effectiveness.” Journal of Marketing Research 31 (August): 351-363.

Rindfleisch, Aric and Christine Moorman. 2001. "The Acquisition and Utilization of Information in New Product Alliances: A Strength of Ties Perspective.” Journal of Marketing 65 (April): 1-18. Robinson, Michael D. and Gerald L. Clore. 2001. "Simulation, Scenarios, and Emotional Appraisal: Testing the Convergence of Real and Imagined Reactions to Emotional Stimuli." Personality and Social Psychology Bulletin 27 (November): 1520-1532.

Roseman, Ira J. 1991. “Appraisal Determinants of Discrete Emotions.” Cognition and Emotion 5 (May): 161-200.

Ruth, Julie A., Frederic F. Brunel, and Cele C. Otnes. 2002. "Linking Thoughts to Feelings: Investigating Cognitive Appraisals and Consumption Emotions in a Mixed-Emotions Context." Journal of the Academy of Marketing Science 30 (Winter): 44-58.

Saarni, Carolyn.1999. The Development of Emotional Competence. New York: Guilford.

Salovey, Peter, Brian T. Bedell, Jerusha B. Detweiler, and John D. Mayer. 2000. “Current Directions in Emotional Intelligence Research.” In Handbook of Emotions. $2^{\text {nd }}$ edition. Eds. Michael Lewis and Jeannette M. Haviland-Jones. New York: Guilford, 504-520.

Schaller, Mark and Robert B. Cialdini. 1990. "Happiness, Sadness, and Helping: A Motivational Integration.” In Handbook of Motivation and Cognition: Foundations of Social Behavior, Vol. 2. Eds. R.M. Sorrentino and E.T. Higgins. New York: Guilford, 527-561.

Seligman, Martin E.P. 2002. "Positive Psychology, Positive Prevention, and Positive Therapy.” In 
Handbook of positive psychology. Eds. C.R. Snyder and Shane J. Lopez. New York: Oxford University, 3-12.

Singh, Jagdip. 2000. "Performance productivity and quality of frontline employees in service organizations.” Journal of Marketing 64 (April): 15-34.

Singh, Jagdip, Goolsby, Jerry R., and Gary K. Rhoads. 1994. "Behavioral and Psychological Consequences of Boundary Spanning Burnout for Customer Service Representatives.” Journal of Marketing Research 31 (November): 558-569.

Skinner, Ellen A. 1999. “Action Regulation, Coping, and Development.” In Action and selfdevelopment: Theory and Research Through the Life Span. Eds. Jochen Brandtstadter and Richard M. Lerner. Thousand Oaks, CA: Sage, 465-504.

Smith, Craig A. and Richard S. Lazarus. 1993. "Appraisal Components, Core Relational Themes, and the Emotions.” Cognition and Emotion 7 (May-July): 233-269.

Smith, Richard H., Gerrod W. Parrott, Edward F. Diener, Rick H. Hoyle, and Sung H. Kim. 1999. “Dipositional Envy.” Personality and Social Psychology Bulletin 25 (August): 1007-1020.

Soldow, Gary F. and Gloria P. Thomas. 1984. "Relational Communication: Form Versus Content in the Sales Interaction.” Journal of Marketing 48 (Winter): 84-93.

Spiro, Rosann L. and Barton A. Weitz. 1990. Adaptive Selling: Conceptualization, Measurement, and Nomological Validity. Journal of Marketing Research 27 (February): 61-69.

Sujan, Harish. 1986. “Smarter versus Harder: An Exploratory Attributional Analysis of Salespeople’s Motivation.” Journal of Marketing Research 23 (February): 40-49.

Sujan, Harish. 1999. “Optimism and Street-Smarts: Identifying and Improving Salesperson Intelligence.” Journal of Personal Selling and Sales Management 19 (Summer): 17-33.

Sujan, Harish, Barton A. Weitz, and Nirmalya Kumar. 1994. "Learning Orientation, Working Smart, and Effective Selling.” Journal of Marketing 58 (July): 39-52.

Szymanski, David M. (1988). "Determinants of Selling Effectiveness: The Importance of Declarative 
Knowledge to the Personal Selling Concept. Journal of Marketing 52 (January): 63-77.

Szymanski, David M. and Gilbert A. Churchill. 1990. "Client Evaluation Cues: A Comparison of

Successful and Unsuccessful Salespeople.” Journal of Marketing Research 27 (May): 162-174.

Tangney, June P. 1999. “The Self-Conscious Emotions: Shame, Guilt, Embarrassment and Pride.” In

Handbook of Cognition and Emotion. Eds. Tim Dalgleish and Mick J. Power. New York: Wiley and Sons, 541-568.

Tangney, June P. and Kurt W. Fischer. 1995. Self-Consciousness Emotions. New York: Guilford.

Thoits, Peggy. A. 1990. "Emotion Deviance: Research Agendas.” In Research Agendas in the Sociology of Emotions. Ed. Theodore D. Kemper. Albany: State University of New York, 180206.

Van Dyne, Linn, Jill W. Graham, and Richard M. Dienesch. 1994. “Organizational Citizenship Behavior: Construct Redefinition, Measurement, and Validation.” Academy of Management Journal 37 (August): 765-802.

Verbeke, Willem and Richard P. Bagozzi. 2000. "Sales Call Anxiety: Exploring What It Means When Fear Rules a Sales Encounter.”Journal of Marketing 64 (July): 88-101.

Verbeke, Willem and Richard P. Bagozzi. 2002. “A Situational Analysis on How Salespeople Experience and Cope With Shame and Embarrassment.” Psychology \& Marketing 19 (September): 713-741.

Verbeke, Willem and Richard P. Bagozzi. 2003. "Exploring the Role of Self- and Customer-Provoked Embarrassment in Personal Selling.” International Journal of Research in Marketing 20 (September): 233-258.

Waldron, Vincent R. 2000. "Relational Experiences and Emotion at Work.” In Emotion in Organizations. $2^{\text {nd }}$ edition. Ed. Stephen Fineman. London: Sage, 64-82.

Weiner, Bernard. 1992. Human Motivation: Metaphors, Theories, and Research. London: Sage. 


\section{APPENDIX 1}

During your quarterly feedback with your sales manager, he/she tells you that you did excellent work. He/she tells you that you performed better than most salespeople and that you now belong to the top 10 of the salespeople. This will be mentioned in the next edition of your organization's newsletter that is being sent to all of your customers. In addition many of your colleagues already congratulated you.

Please express how strongly you feel in each of the following cases...

1. Now I know quite well what I have to do to be a good salesperson.

2. Now I have self-assurance how I can reach my sales quota's.

3. I am now convinced that I can persuade my customers to buy from me.

4. I feel exuberant and exhilarated.

5. I feel invincible.

6. I feel proud. 


\section{APPENDIX 2}

"During your quarterly feedback with your sales manager, he/she tells you that you did excellent work and that you now belong to the top 10 of the salespeople. In the next edition of your organization magazine this will be announced, in fact many of your customers also read this magazine."

Please express how strongly you feel each of the following...

Deep inside I think (positive pride)

1. Now I know quite well what I have to do to be a good salesperson

2. Now I have self-assurance how I can reach my sales quota's

3. I am now convinced that I can persuade my customers

Deep inside I think (hubris)

4. I often think: "See I am a good salesperson"

5. I always thought: "I am a real salesperson"

6. I think I am a top salesperson

Deep inside I feel (subjective experience)

7. exuberant and exhilarated.

8. invincible.

9. proud.

Having read those sentences what tendencies do you have (action tendencies):

10. I feel an urge to tell my colleagues I am doing well.

11. I have a strong desire to tell colleagues I am the best.

Having shown my pride to colleagues (customers)...

Negative self-conscious emotions:

12. I feel ashamed that I could not contain my pride to colleagues (customers).

13. I regret that my colleagues (customers) could see my pride.

Fear:

14. I think my colleagues (customers) will gossip I am a bigheaded person.

15. I think my colleagues (customers) will seek to match my accomplishments.

16. I think my colleagues (customers) will avoid me. 
Table 1. Pretest results: Frequency and intensity of emotions at work (means with standard deviations in parentheses).

\begin{tabular}{lll}
\hline Emotion & Frequency & Intensity \\
\hline Pride & $5.04(.96)$ & $5.16(1.11)$ \\
Hubris (excessive pride) & $3.43(1.61)$ & $3.67(1.61)$ \\
Shame & $2.27(1.11)$ & $2.57(1.34)$ \\
Guilt & $2.40(.99)$ & $2.70(1.30)$ \\
Envy & $2.11(1.04)$ & $2.25(1.06)$ \\
Embarrassment & $2.25(1.01)$ & $2.60(1.25)$ \\
Jealousy & $2.37(1.17)$ & $2.37(1.07)$ \\
Joy & $5.35(.93)$ & $5.40(.98)$ \\
Disappointment & $3.62(1.09)$ & $3.96(1.40)$ \\
Anger & $3.17(1.13)$ & $3.43(1.47)$ \\
Sales call anxiety & $1.93(1.01)$ & $2.03(.96)$ \\
\hline
\end{tabular}

Frequency was measured on a 7-point scale (1=never, 7 always), and intensity was measured on a 7-point scale ( $1=$ not at all, $7=$ very intensely). $\underline{N}=141$. 
Table 2. Reliability (alpha), means, and standard deviations of the scales from Study 1.

\begin{tabular}{|c|c|c|c|c|c|}
\hline Scales & & $\begin{array}{l}\text { Number of } \\
\text { items }\end{array}$ & Alpha & Means & $\begin{array}{c}\text { Standard } \\
\text { deviations }\end{array}$ \\
\hline \multicolumn{6}{|c|}{ In-role performance } \\
\hline & Pride & 6 & .70 & 5.71 & .64 \\
\hline & Adaptive selling & 8 & .86 & 5.66 & .81 \\
\hline & Working hard & 3 & .73 & 5.26 & 1.05 \\
\hline & Self-efficacy & 7 & .66 & 5.33 & .77 \\
\hline \multicolumn{6}{|c|}{ Extra-role performance } \\
\hline & Helping & 3 & .83 & 5.42 & 1.05 \\
\hline & Sportsmanship & 4 & .83 & 5.71 & 1.13 \\
\hline & Civic Virtue & 3 & .77 & 5.19 & .96 \\
\hline & Courtesy & 4 & .80 & 5.20 & 1.03 \\
\hline
\end{tabular}


Table 3. The broadening effects of pride (standardized coefficients) (Study 1).

\section{Dependent variables (In-role performance)}

\begin{tabular}{lccc}
\hline $\begin{array}{l}\text { Independent } \\
\text { variables }\end{array}$ & Adaptive selling & Working hard & Self-efficacy \\
\hline Pride & $.51^{* *}$ & $.28^{* *}$ & $.56^{* *}$ \\
\multicolumn{1}{c}{ Adjusted $\underline{\mathrm{R}}^{2}$} & .25 & .07 & .31 \\
\hline Pride & $.50^{* *}$ & $.26^{*}$ & $.56^{* *}$ \\
Work experience & .12 & .12 & -.04 \\
Age & -.02 & .10 & -.01 \\
Education & -.07 & .06 & -.16 \\
\multicolumn{1}{c}{ Adjusted $\underline{\mathrm{R}}^{2}$} & .24 & .07 & .31 \\
\hline
\end{tabular}

Dependent variables (Extra-role performance)

\begin{tabular}{llccc}
\hline $\begin{array}{l}\text { Independent } \\
\text { variables }\end{array}$ & \multicolumn{1}{c}{ Civic virtue } & Sportsmanship & Helping & Courtesy \\
Pride & \multicolumn{1}{c}{$.34^{* *}$} & .15 & $.37^{* *}$ & $.26^{* *}$ \\
\multicolumn{1}{c}{ Adjusted $\underline{\mathrm{R}}^{2}$} & .11 & .01 & .13 & .06 \\
\hline Pride & $.35^{* *}$ & .14 & $.38^{* *}$ & $.26^{*}$ \\
Work experience & $.29^{*}$ & .09 & .14 & .12 \\
Age & -.09 & -.06 & .03 & .11 \\
Education & -.02 & -.04 & $.23 *$ & $.27^{*}$ \\
\multicolumn{1}{c}{ Adjusted $\underline{\mathrm{R}}^{2}$} & .14 & .00 & .16 & .10 \\
\hline
\end{tabular}

$* \mathrm{p}<.05 \quad * * \mathrm{p}<.01$ 
Table 4. Reliability (alphas), means, and standard deviations of the scales in Study 2.

\begin{tabular}{|c|c|c|c|c|c|}
\hline Scales & & $\begin{array}{l}\text { Number of } \\
\text { items }\end{array}$ & Alpha & Means & $\begin{array}{c}\text { Standard } \\
\text { deviations }\end{array}$ \\
\hline \multirow[t]{8}{*}{ Hubris } & Cognitive appraisal & 3 & .83 & 4.12 & 1.50 \\
\hline & Subjective experience & 3 & .80 & 5.13 & 1.25 \\
\hline & Action tendencies colleagues & 2 & .84 & 2.64 & 1.45 \\
\hline & Neg. SC-emotions colleagues & 2 & .86 & 3.01 & 1.65 \\
\hline & Fear colleagues & 3 & .88 & 2.51 & 1.42 \\
\hline & Action tendencies customer & 2 & .86 & 2,22 & 1.30 \\
\hline & Neg. SC-emotions customer & 2 & .88 & 3.02 & 1.75 \\
\hline & Fear customer & 3 & .91 & 2.52 & 1.55 \\
\hline \multirow[t]{8}{*}{ Pride } & Cognitive appraisal & 3 & .79 & 5.05 & 1.10 \\
\hline & Subjective experience & 3 & .84 & 5.30 & 1.17 \\
\hline & Action tendencies colleagues & 2 & .88 & 3.08 & 1.58 \\
\hline & Neg. SC-emotions colleagues & 2 & .84 & 3.10 & 1.59 \\
\hline & Fear colleagues & 3 & .90 & 2.50 & 1.40 \\
\hline & Action tendencies customer & 2 & .88 & 2.16 & 1.27 \\
\hline & Neg. SC-emotions customer & 2 & .90 & 3.04 & 1.79 \\
\hline & Fear customer & 3 & .92 & 2.38 & 1.53 \\
\hline
\end{tabular}


Table 5. Correlation matrix of constructs, Study 2.

\begin{tabular}{|c|c|c|c|c|c|c|c|c|c|c|c|c|c|c|}
\hline & 1 & 2 & 3 & 4 & 5 & 6 & 7 & 8 & 9 & 10 & 11 & 12 & 13 & 14 \\
\hline $\begin{array}{l}\text { 1. Cognitive } \\
\text { appraisal hubris }\end{array}$ & & & & & & & & & & & & & & \\
\hline $\begin{array}{l}\text { 2. Subjective } \\
\text { experience hubris }\end{array}$ & $.55^{* *}$ & & & & & & & & & & & & & \\
\hline $\begin{array}{l}\text { 3. Action tendencies } \\
\text { Colleagues hubris }\end{array}$ & $.34^{* *}$ & $.18^{* *}$ & & & & & & & & & & & & \\
\hline $\begin{array}{l}\text { 4. Negative SC- } \\
\text { emotions } \\
\text { colleagues hubris }\end{array}$ & $.19^{* *}$ & .05 & .10 & & & & & & & & & & & \\
\hline $\begin{array}{l}\text { 5. Fear colleagues } \\
\text { (hubris) }\end{array}$ & $.21^{* *}$ & .10 & $.23 * *$ & $.67 * *$ & & & & & & & & & & \\
\hline $\begin{array}{l}\text { 6. Action tendencies } \\
\text { customers hubris }\end{array}$ & $.26^{* *}$ & .01 & $.59 * *$ & $.21^{* *}$ & $.29 * *$ & & & & & & & & & \\
\hline $\begin{array}{l}\text { 7. Negative SC- } \\
\text { emotions } \\
\text { customers hubris }\end{array}$ & $.15^{*}$ & .03 & .08 & $.69 * *$ & $.64 * *$ & $.21 * *$ & & & & & & & & \\
\hline $\begin{array}{l}\text { 8. Fear customers } \\
\text { (hubris) }\end{array}$ & $.15^{*}$ & .02 & $.15^{*}$ & $.60 * *$ & $.73 * *$ & $.23 * *$ & $.80^{* *}$ & & & & & & & \\
\hline $\begin{array}{l}\text { 9. Cognitive } \\
\text { appraisal pride }\end{array}$ & $.36^{* *}$ & $.34 * *$ & .12 & .09 & .07 & .01 & .01 & -.04 & & & & & & \\
\hline $\begin{array}{l}\text { 10. Subjective } \\
\text { experience pride }\end{array}$ & $.34^{* *}$ & $.55^{* *}$ & .11 & .00 & -.00 & -.04 & -.07 & -.10 & $.64 * *$ & & & & & \\
\hline $\begin{array}{l}\text { 11. Action } \\
\text { tendencies } \\
\text { colleagues pride }\end{array}$ & $.29^{* *}$ & $.16^{*}$ & $.41^{* *}$ & .08 & $.13 *$ & $.34 * *$ & .04 & .11 & $.34 * *$ & $.27 * *$ & & & & \\
\hline $\begin{array}{l}\text { 12. Negative SC- } \\
\text { emotions }\end{array}$ & .06 & .01 & .09 & $.62 * *$ & $.43^{* *}$ & $.24 * *$ & $.58^{* *}$ & $.48 * *$ & .11 & .07 & .07 & & & \\
\hline
\end{tabular}




\begin{tabular}{|c|c|c|c|c|c|c|c|c|c|c|c|c|c|c|c|}
\hline \multirow[b]{2}{*}{$\begin{array}{l}\text { 13. Fear colleagues } \\
\text { (pride) }\end{array}$} & & \\
\hline & .06 & -.01 & $.20 * *$ & $.48^{* *}$ & $.64 * *$ & $.31 * *$ & $.50 * *$ & $.61 * *$ & -.01 & -.01 & $.13^{*}$ & $.68 * *$ & & & \\
\hline $\begin{array}{l}\text { 14. Action } \\
\text { tendencies }\end{array}$ & $.15^{*}$ & -.01 & $.47 * *$ & .12 & $.24 * *$ & $.57 * *$ & .13 & $.21 * *$ & -.00 & -.06 & $.48 * *$ & $.19 * *$ & $.31 * *$ & & \\
\hline $\begin{array}{l}\text { customers pride } \\
\text { 15. Negative SC- } \\
\text { emotions }\end{array}$ & .11 & -.05 & .07 & $.60 * *$ & $.46^{* *}$ & $.19 * *$ & $.70 * *$ & $.59 * *$ & .10 & -.01 & .04 & $.73 * *$ & $.59 * *$ & $.21^{* *}$ & \\
\hline $\begin{array}{l}\text { customers pride } \\
\text { 16. Fear customers } \\
\text { (pride) }\end{array}$ & $.13^{*}$ & -.03 & $.17^{*}$ & $.53 * *$ & $.64 * *$ & $.25^{* *}$ & $.62 * *$ & $.72 * *$ & -.02 & -.05 & .11 & $.60 * *$ & $.78 * *$ & $.26 * *$ & $.73 * *$ \\
\hline
\end{tabular}

$* \mathrm{p}<.05$ (2-tailed); ** $\mathrm{P}<.001$ (2-tailed) 
Table 6. Tests of differences between selected paths for pride and for hubris, Study 2.

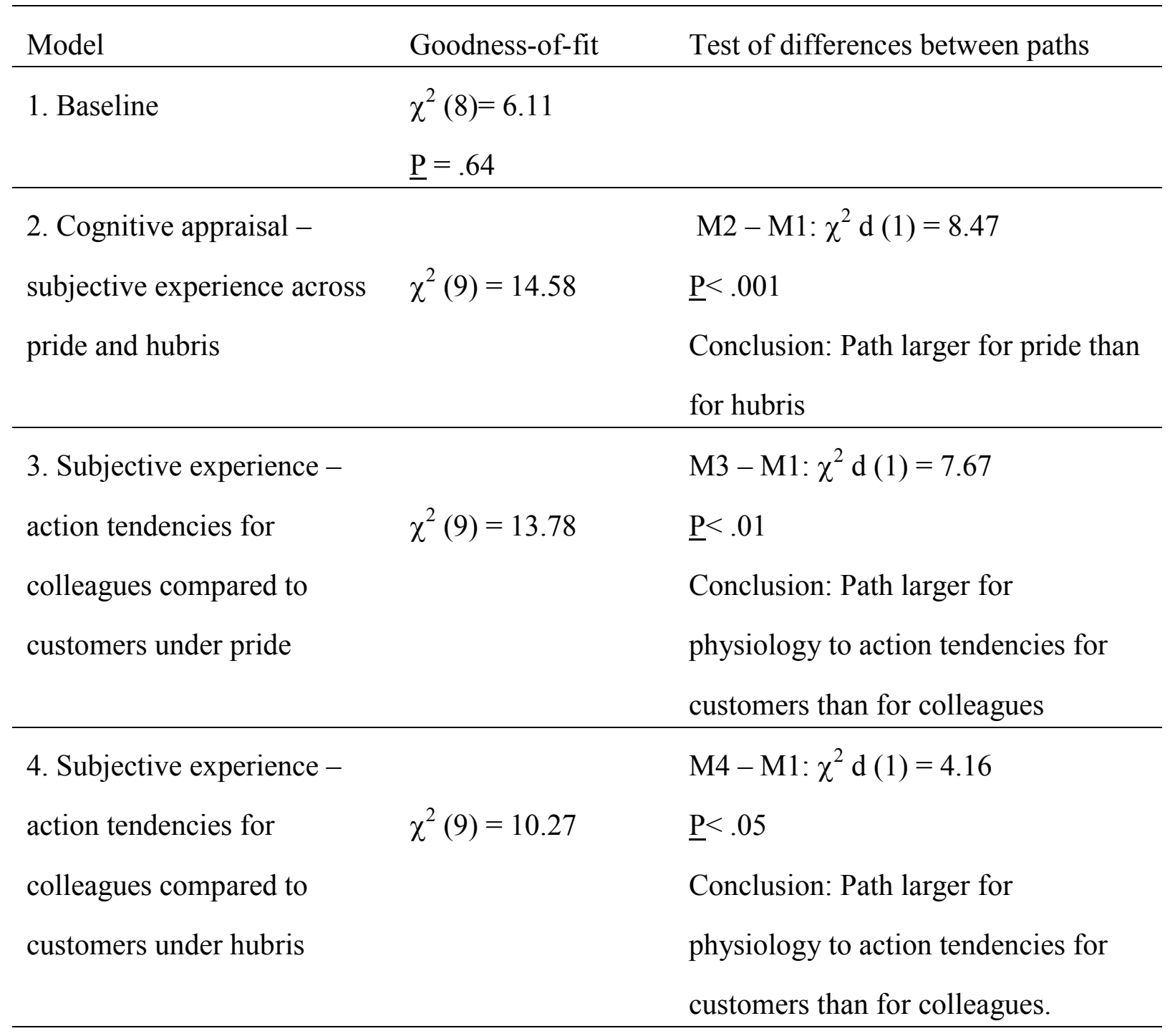


Figure 1. Path model for pride and for hubris, Study 2.

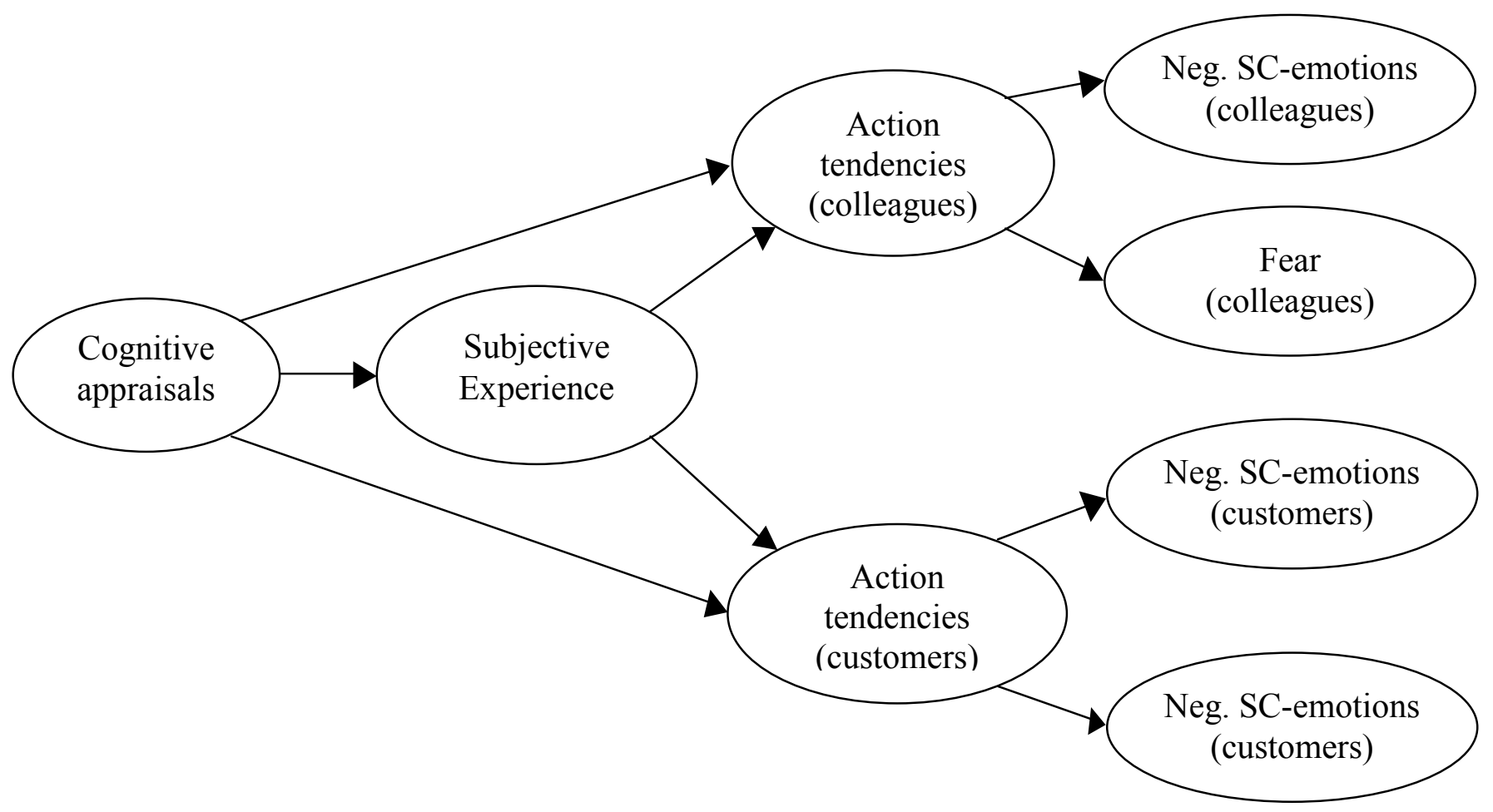


Figure 2. Path model for tests of Hypotheses 3-6, Study 2 (standardized parameter estimates).

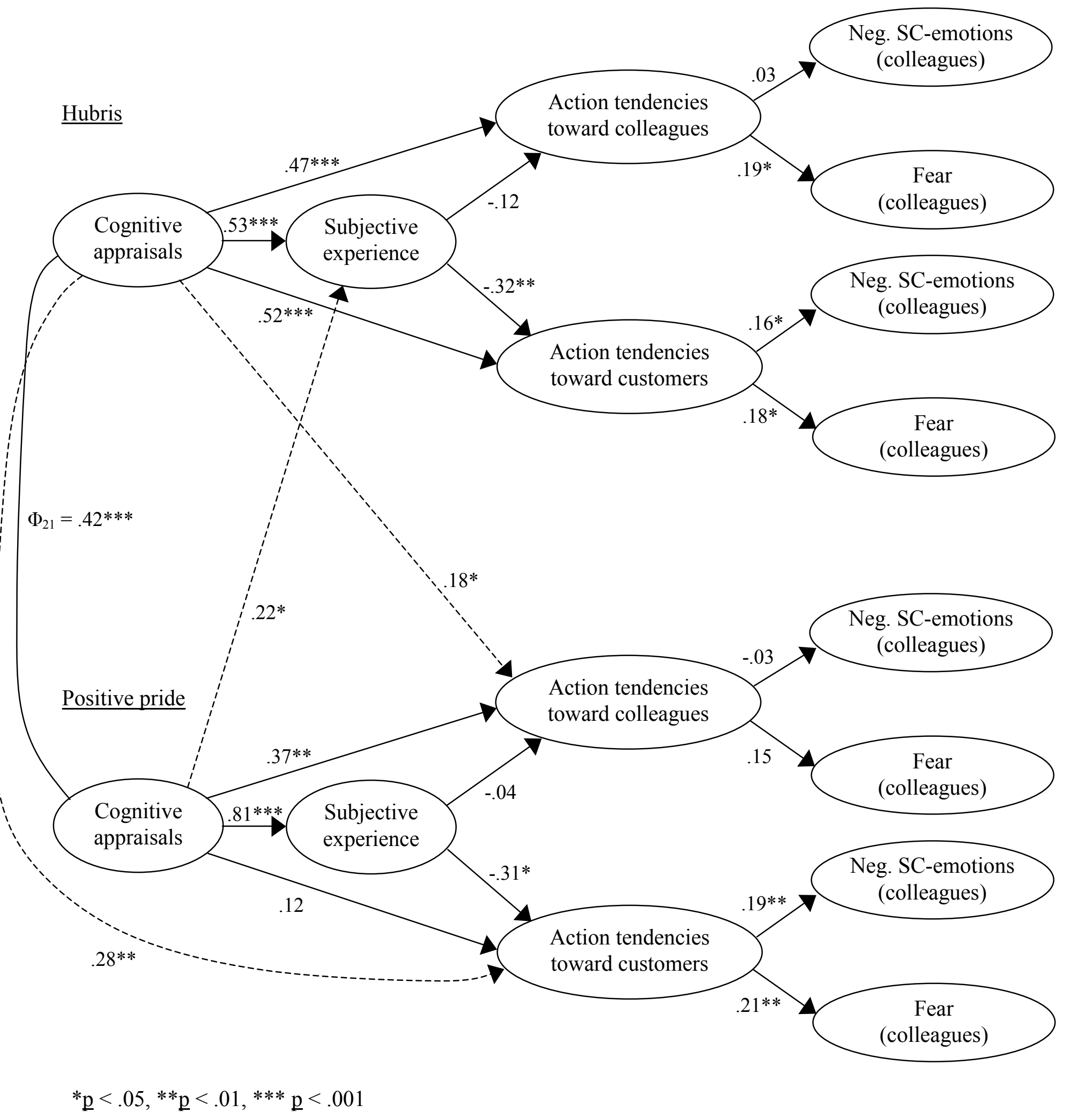

Note: Correlated errors among latent variables and nonsignificant paths not hypothesized are omitted for simplicity. 


\section{Publications in the Report Series Research* in Management}

\section{ERIM Research Program: "Marketing"}

2004

Account Managers Creation of Social Capital: Communal and Instrumental Investments and Performance Implications Willem Verbeke, Frank Belschak, Stefan Wuyts and Richard P. Bagozzi ERS-2004-011-MKT

http://hdl.handle.net/1765/1166

The Adaptive Consequences of Pride in Personal Selling Willem Verbeke, Frank Belschak and Richard P. Bagozzi ERS-2004-012-MKT

* A complete overview of the ERIM Report Series Research in Management: https://ep.eur.nl/handle/1765/1

ERIM Research Programs:

LIS Business Processes, Logistics and Information Systems

ORG Organizing for Performance

MKT Marketing

F\&A Finance and Accounting

STR Strategy and Entrepreneurship 